$\mathrm{DE}$

M E D I C I N A

T R O P I C A L

DE

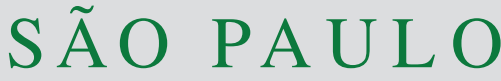

JOURNAL OF THE SÃO PAULO INSTITUTE OF TROPICAL MEDICINE

'Universidade de São Paulo, Faculdade de Medicina, Hospital das Clínicas, Grupo do Ambulatório de Imunodeficiências Secundárias, São Paulo, São Paulo, Brazil

2Universidade de São Paulo, Instituto de Medicina Tropical de São Paulo, LIM-56, São Paulo, São Paulo, Brazil

Correspondence to: Jorge Casseb Universidade de São Paulo, Instituto de Medicina Tropical de São Paulo, LIM-56, Av. Dr. Eneas de Carvalho Aguiar, 500, Prédio 2, $3^{\circ}$ Andar, CEP 5403000, São Paulo, SP, Brazil

Tel: +55 11 3061-7193, +55 113081-7190

E-mail: jcasseb@usp.br

Received: 24 September 2019

Accepted: 20 March 2020

\section{Fighting HIVIAIDS in a developing country: lessons from a small cohort from the largest Brazilian city}

São Paulo, September 24 $4^{\text {th }}, 2019$
Strategies aimed at managing human immunodeficiency virus (HIV)-infected and AIDS patients have been well-succeeded in decreasing morbidity and mortality due to the disease, whose worldwide estimated numbers reached 38 million people in 20181. Brazil introduced its HIV/ AIDS program in 1996, consisting of multidisciplinary monitoring and treatment for all known people living with HIV. In addition, screening and monitoring tests are available using the Brazilian health system (SUS). Furthermore, campaigns aimed at preventing new infections, focused on safe sex with the use of condoms and other practices have been implemented with variable success, as well as the antiretroviral therapy free of charge for treatment and more recently, as a prevention strategy ${ }^{2}$. Estimates point to 900,000 persons living with HIV in the country, 590,000 on antiretroviral treatment (ART) and 550,000 of them with suppressed viral loads levels ${ }^{3}$.

We implemented a multidisciplinary care for HIV/AIDS people in our outpatient clinic, where we have cared for 800 patients from its inception, in 1983. Four hundred and thirty $(55 \%)$ of these patients are still been followed-up ${ }^{4}$, one of them with more than 30 years of active follow-up. Since 1996, when Brazilian HIV/ AIDS program was implemented, with widely guided ART, the total mortality of our patients declined and reached six percent. The mean follow-up time of our cohort is 13 years, and all but six of our currently followed-up patients are not on antiretroviral therapy by their own choice. Thus, the adherence level is higher than 95 percent; the latter was measured as the total amount of pills taken during the week before evaluation ${ }^{5}$.

We have some hypotheses to explain our successful strategy, such as:

1. Our outpatient clinic located at Hospital das Clinicas, Faculdade de Medicina da Universidade de Sao Paulo, has a long experience in HIV-patients' care, of more than 30 years; illustrating this, a few of our patients that still remain in the clinic are part of the "original" ones, from the inception of the service. The mortality rate in this cohort was approximately six percent in these 30 years ${ }^{6}$;

2. We have a pre-medical appointment team is composed of two nurses, a nutritionist and a psychotherapist. It is possible that this approach is helping the early identification of comorbidities, such as hypertension, renal diseases, obesity, smoking, risk of falls and bone fractures, as well as the adherence to the follow-up, treatment and medications;

3. Since adherence would be the major challenge for some specific groups of patients, an easy and practical questionnaire is applied to all patients ${ }^{6}$. There is also a direct mobile phone number line exclusive to these patients and their relatives;

4. For the routine medical care, we count on six infectious disease specialists and two senior clinical consultants, highly experienced on the discussion of clinical cases;

5. Depression and anxiety are managed by experienced and motivated psychologists, aiming at preventing the further worsening of symptoms, caring 
for the patients who were identified during regular medical consultation;

6. Adherence issues are managed in small groups of up to five patients, with the supervision of a therapist, sometimes including a discussion wheel to improve the patients' adherence to $\mathrm{ART}^{7}$. For most of these patients, when needed, antidepressive and/ or anti-anxiety medications are used. More severe cases are managed by a psychiatrist;

7. During the regular follow-up, HIV-1 plasma viral load (PVL) and CD4 T-cells counts are routinely performed every six months, along with pre-ART genotyping tests. The surveillance of drug failure is requested for all patients with viral load levels higher than 200 copies $/ \mathrm{mL}$, which is the detection limit in our laboratory. The genotyping test may guide the ART decision, raising the possibility to choose more effective treatment regimens.

Figure 1 shows the algorithm used in our clinic in the last two decades. Despite all the strategies described above, among 430 patients are on active follow-up, 401 of them presented viral load levels below the detectable limit (< 40 copies $/ \mathrm{mL}$ ). Patients with viral load levels higher than 40 copies/mL (29 cases) were contacted by the nurse and an extra appointment was scheduled. Most of them showed up, they were re-tested and an adherence questionnaire was applied. During the extra appointment, nurse, psychologist, nutritionist and infectious diseases specialist (ID) were present. We had a total of three visits of failure cases for samples recollection and meeting with these cases. From the potential 29 patients, 23 showed up for the extra appointments: 14 cases had already a viral load $<40$ copies/mL; and nine patients presented viral load levels over this limit of detection. The lack of adherence was the major problem, which we addressed and discussed with them, suggesting possible strategies to improve their motivation to adhere to the clinic and treatment.

Figure 2 shows the evolution of resistance to antiretroviral drugs, characterized as a viral load higher than 200 copies/mL, throughout the follow-up time and according to the proportion of patients still remaining in the cohort. It is possible to observe that the proportion of viral load levels below 200 copies/ mL was inversely correlated to the number of genotyping tests (Figure 2) and directed correlated to the adherence. However, the most important would be to restore the immune response, crucial to prevent cancers and opportunistic infections. Indeed, there was a strong recovery of the T CD4+ cells, with only a few cases with values below 350 cells $/ \mathrm{mm}^{3}$, considered the limit for immune dysfunction among our patients.

How can we explain the success of our long-term strategy? The multidisciplinary team approach and

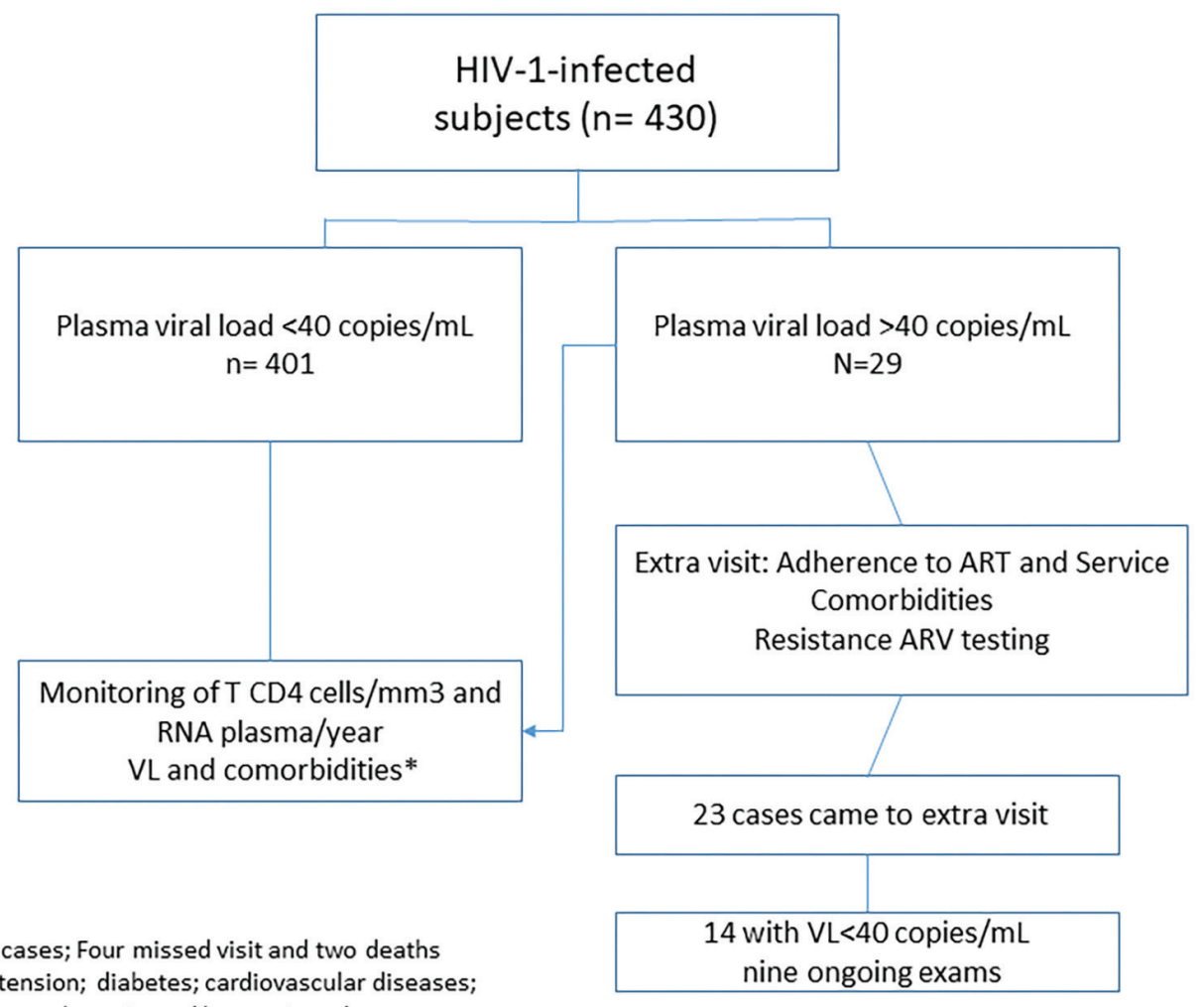

Notes: Four naive cases; Four missed visit and two deaths Comorbidities: Hypertension; diabetes; cardiovascular diseases; nine ongoing exams

Figure 1 - Algorithm used to define successful strategies to reach HIV control. 


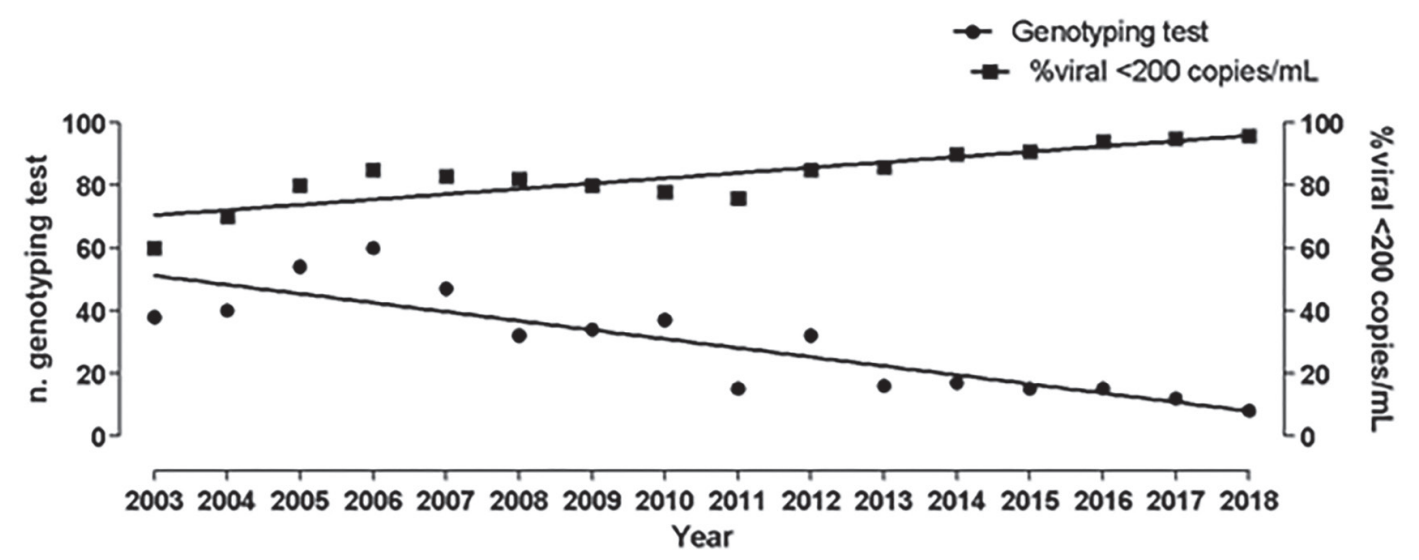

Figure 2 - Evaluation of HIV viral load and number of genotyping tests during the 15 years at the ADEE3002 cohort after ART.

improved, simpler-to-take new ART drugs such as integrase inhibitors may be the keys of our good results. However, despite that success in a clinical point of view, new challenges are still on the way, such the onset of cardiovascular diseases ${ }^{8}$, 6Vitamin D deficiency ${ }^{9}$, depression/ anxiety ${ }^{10,11}$, osteopenia/ osteoporosis ${ }^{12}$. More recent challenges are the development of HIV-associated neurological diseases (HAND), which were found in almost $40 \%$ of patients on active follow-up. These conditions may impact the adherence to treatment and the patients may present with lack of ART efficacy that should be checked by genotyping tests ${ }^{13}$, higher viremia, and drop in T CD4+ cells counts, leading to higher morbidity and mortality ${ }^{3}$. These are the issues to be addressed in the near future, and again a multidisciplinary approach would be more up to the task.

\author{
Jorge Casseb ${ }^{\circledR 1,2}$ \\ Ana Paula R. Veiga ${ }^{1,2}$ \\ Marcello M. C. Magri ${ }^{1,2}$ \\ Mariana A. Monteiro ${ }^{1,2}$ \\ Rosana C. Rocha ${ }^{1,2}$ \\ Maria Rita P. Gascon ${ }^{1,2}$ \\ Mauricio Domingues-Ferreira ${ }^{\circledR 1,2}$ \\ Thales J. B. Polis ${ }^{1,2}$ \\ Najara A. de Lima Nascimento ${ }^{1,2}$ \\ Isadora Limongelli ${ }^{1,2}$ \\ Ícaro S. Oliveira ${ }^{1,2}$ \\ Gabriela Caetano Prandi ${ }^{1}$ \\ Livia M. C. B. Villares Costa ${ }^{1}$ \\ Luiz A. M. Fonseca ${ }^{1,2}$ \\ Alberto J. S. Duarte ${ }^{1,2}$
}

\section{ACKNOWLEDGMENTS}

We dedicated this work for all the patients along 30 years and ex-medical residents. We thank the volunteers Maria Olimpia Ribeiro Freitas and Maria Tereza de Figueiredo for more the 20 years of work in the Ambulatório de Imunodeficiências Secundárias do Hospital das Clínicas da Universidade de São Paulo.

\section{FUNDING}

Fapesp, grant No 2014/22827-7; Ministério da Saúde; Fundação Faculdade de Medicina; and CNPq, grant $\mathrm{N}^{\circ} 301372 / 2013-6$

\section{REFERENCES}

1. UNAIDS Joint United Nations Programme on HIV/AIDS. UNAIDS data 2019. [cited 2020 Mar 20]. Available from: https://www.unaids.org/sites/default/files/media_asset/2019UNAIDS-data_en.pdf

2. Casseb J, Orrico GS, Feijo RD, Guaracy L, Medeiros LA. Lack of prior antiretroviral therapy is associated with increased mortality among hospitalized patients with AIDS in Sao Paulo, Brazil. AIDS Patient Care STDS. 2001;15:271-5.

3. Brasil. Ministério da Saúde. Secretaria de Vigilância em Saúde. Boletim epidemiológico HIV AIDS 2018. [cited 2020 Mar 20]. Available from: http://www.aids.gov.br/pt-br/pub/2018/ boletim-epidemiologico-hivaids-2018

4. Fonseca LA, Reingold AL, Casseb JR, Brigido LF, Duarte AJ. AIDS incidence and survival in a hospital-based cohort of asymptomatic HIV seropositive patients in São Paulo, Brazil. Int J Epidemiol. 1999;28:1156-60.

5. Sabino T, Monteiro M, Casseb J. Uso do CEATH para avaliar adesão ao tratamento antirretroviral de pessoas vivendo com HIV/AIDS: associação da carga viral com o grau de adesão. $19^{\circ}$ Congresso Brasileiro de Infectologia; 2015 Aug 26-29, Gramado, RS.

6. Casseb J, Fonseca LA, Duarte A. Is it possible to control HIV infection in a middle-income country through a multidisciplinary approach? AIDS Res Hum Retroviruses. 2018;34:165-7. 
7. Brigido LF, Rodrigues R, Casseb J, Oliveira D, Rossetti M, Menezes $\mathrm{P}$, et al. Impact of adherence to antiretroviral therapy in HIV-1-infected patients at a university public service in Brazil. AIDS Patient Care STDS. 2001;15:587-93.

8. Soares LR, da Silva DC, Gonsalez CR, Batista FG, Fonseca LA, Duarte AJ, et al. Discordance between body mass index and anthropometric measurements among HIV-1-infected patients on antiretroviral therapy and with lipoatrophy/ lipohypertrophy syndrome. Rev Inst Med Trop Sao Paulo. 2015;57:105-10.

9. Sales SH, Matta SM, da Silva DC, Assone TA, Fonseca LA, Duarte $\mathrm{AJ}$, et al. High frequency of deficient consumption and low blood levels of 25-hydroxyvitamin D in HIV-1-infected adults from São Paulo city, Brazil. Sci Rep. 2015;5:12990.

10. Gascón MR, Vidal JE, Mazzaro YM, Smid J, Marcusso RM, Capitão CG, et al. Neuropsychological assessment of 412 HIV-infected individuals in São Paulo, Brazil. AIDS Patient Care STDS. 2018;32:1-8.
11. Moraes RP, Casseb J. Depression and adherence to antiretroviral treatment in HIV-positive men in São Paulo, the largest city in South America: social and psychological implications. Clinics (Sao Paulo). 2017;72:743-9.

12. Chaba DC, Soares LR, Pereira RM, Rutherford GW, Assone T, Takayama L, et al. Low bone mineral density among HIVinfected patients in Brazil. Rev Inst Med Trop Sao Paulo. 2017;59:e89.

13. Brasil. Ministério da Saúde. Secretaria de Vigilância em Saúde. Protocolo clínico e diretrizes terapêuticas para manejo da infecção pelo HIV em crianças e adolescentes. Brasília: Ministério da Saúde; 2018. [cited 2020 Mar 20]. Available from: http://www.aids.gov.br/pt-br/pub/2017/protocoloclinico-e-diretrizes-terapeuticas-para-manejo-da-infeccaopelo-hiv-em-criancas-e 